\title{
Impact of runoff prediction on grey water footprint in a small agricultural catchment
}

\author{
Leszek Hejduk, Agnieszka Hejduk
}

Warsaw University of Life Sciences, Faculty of Civil and Environmental Engineering, Nowoursynowska 159, 02-776Warsaw,Poland, e-mail: leszek_hejduk@sggw.pl,agnieszka_hejduk@sggw.pl

\begin{abstract}
According to Hoekstra et al. (2011) the water footprint within a geographic area is defined as the total freshwater consumption and pollution within the boundaries of the area. The grey part of the water footprint refers to pollution and is an indicator of the water volume needed to assimilate a pollutant load that reaches a water body. It is possible then, based on the grey water footprint to estimate if the water available in a river at a particular crosssection will be sufficient to maintain a water pollution level (WPL) below $100 \%$. The crossing of $100 \%$ indicates that the waste assimilation capacity has been fully consumed in this particular catchment.

In this paper, the grey water footprint from nonpoint source pollution has been calculated based on long-term hydrometrological data for the upper part of a small agricultural catchment (area of $23.4 \mathrm{~km}^{2}$ ) (Zagożdżonka River) in central Poland. Based on land use and the amount of fertilizers applied in the catchment, together with information about the natural concentration of nitrogen and phosphorus in the river, as well as maximum acceptable concentration, the water pollution level has been calculated for actual conditions. The estimation of future runoff decreases for the considered catchment (Banasik, Hejduk 2012) has been applied in order to estimate potential future water pollution levels. The calculation shows that, even when the management practices in this catchment remain as they are, including the current extensive crop production, the WPL of $100 \%$ will be exceeded in the year 2033 (for phosphorus) and 2043 (for nitrogen) due only to the decreasing availability of water.
\end{abstract}

Keywords: grey water footprint, water pollution level, catchment

Submitted 4 May 2018, revised 31 July 2018, accepted 24 August 2018

\section{Introduction}

Grey water footprint $(G W F)$ is one measure of pollution levels in aquatic systems. According to Hoekstra et al. (2011) the grey water footprint is defined as the volume of freshwater that is required to assimilate the load of pollutants based on natural background concentrations and existing ambient water quality standards. It can be applied for example to estimate the wastewater dilution processes in industry (Martínez-Alcalá et al. 2018 ) or to estimate water consumption for construction materials (Gerbens-Leenes et al. 2018). In agriculture the grey water footprint can be used for crop production as a tool for optimizing planting patterns (Mali et al. 2017). The calculations used here have been used to estimate the $G W F$ as well as the assimilation capacity (i.e., the capacity to receive wastewater or toxic materials without deleterious effects to people and other life forms) at a river basin scale in other case studies (Zhi et al. 2015; Li et al. 2017). The GWF can also help to estimate anthropogenic trends in the input of nitrate and phosphorus into rivers (Liu et al. 2012). Based on Liu et al. 2012, calculation the basins of Vistula and Odra river are endanger of an increased water pollutant level (measure of degree of water pollution).
The water pollution level (WPL) for dissolved inorganic nitrogen and dissolved inorganic phosphorus until 2030 can reach a value of $2-5$. A threshold value of 1 or $100 \%$ means that the waste assimilation capacity has been fully consumed; therefore a range between 2 and 5 indicates potentially significant problems with water pollution.

This investigation of a small agricultural catchment in central Poland had a several aims. The first was to research the possible application of GWF to estimate future water quality change with regard to nitrogen and phosphorus. The second aim was to check how water quality standards influence grey water footprint values. The third aim was to estimate when the water pollution levels are expected to exceed the threshold of 1 (or 100\%), which indicates the remaining time to apply mitigation options in this catchment.

\section{Methods}

\subsection{Catchment description}

The study was carried out in the upper part of the Zagożdżonka River catchment (Fig. 1) located in central Poland, approximately $100 \mathrm{~km}$ south of Warsaw. Hydrological investigation of the Zagożdżonka River was started 
by the Department of Hydraulic Engineering of Warsaw University of Life Science in 1962 at Płachty Stare gauge (point A, Fig. 1). The catchment area of Płachty Stare is $82.4 \mathrm{~km}^{2}$ and Czarna is $23.4 \mathrm{~km}^{2}$ (point B, Fig. 1). The mean elevation of the catchment is about $163 \mathrm{~m}$ above sea level (ASL), and the absolute relief is $37.0 \mathrm{~m}$ (or 147.5 to $184.5 \mathrm{~m} \mathrm{ASL}$ ). The mean slopes of the main channels range from 2.5 to $3.5 \mathrm{~m}$ per $1000 \mathrm{~m}$. Land use is dominated by arable land (small grains and potatoes), which takes up about $48 \%$ of the catchment. About $41 \%$ is covered by forest and $11 \%$ is pasture (Banasik 1994). Sandy soils are dominant in the watershed area (loamy sand, $27.2 \%$; light loamy sand, $60.6 \%$; and organic soils, $12.1 \%$ ). The yearly average discharge $(S Q)$ at Czarna gauge from long-term observations (1991-2012) were estimated as $0.089 \mathrm{~m}^{3} \cdot \mathrm{s}^{-1}$.

Previous water quality investigations started in 1993 in the Zagożdżonka catchment were mainly focused on phosphorus and nitrogen (Hejduk et al. 2010). Based on 3 years of investigations (Banasik et al. 1996) the allowed concentration of total phosphorus (over $0.25 \mathrm{mgP} \mathrm{dm}^{-3}$ ) was exceeded in $80 \%$ of samples. Investigations conducted between 2008 and 2010 show an improvement of water quality over time. For example, the percentage of samples with very good water quality for total phosphorus (i.e., concentrations lower than $0.2 \mathrm{mgP} \mathrm{dm}^{-3}$ ) increased from $5 \%$ in the years $1993-1995$ to $84 \%$ in the years 2008-2010. However water quality with respect to nitrates decreased; the percentage of good quality samples (i.e., concentrations lower than $2.2 \mathrm{mg} \mathrm{N}-\mathrm{NO}_{3} / \mathrm{l}$ ) drop from 91 to $58 \%$ (Hejduk et al. 2014). The impact of drought and low water flow on water quality for the upper part of the Zagożdżonka catchment was also considered for a limited number of parameters. That analysis indicated that the lowest concentration of nitrate occurred during the summer months and the lowest concentration of phosphate was noticed during the winter months. The highest daily average load of nitrates and phosphates occurred during the winter and the lowest took place during the low flow periods (Kaznowska, Hejduk 2011).

\subsection{Calculation of grey water footprint and water pollution level}

\subsubsection{General equation}

According to Hoekstra et al. (2011) the water footprint $(W F)$ within a geographic area is defined as the total freshwater consumption and pollution within the boundaries of the area. The $W F$ is a sum of the footprints of all water using processes in the areas:

$$
W F_{\text {area }}=\Sigma_{q} W F_{\text {proc }}[q] \text { (volume/time) }
$$

where $W F_{\text {proc }}[q]$ refers to the water footprint of a process q within the area and:

$$
W F_{\text {proc }}=W F_{\text {proc green }}+W F_{\text {proc blue }}+W F_{\text {proc grey }}
$$

The analysis described in this article is focused only on grey water footprint. The grey water footprint $(G W F)$ of a process, $W F_{\text {proc green }}$ (volume/time), can be calculated by using the following equation:

$$
G W F=\frac{L}{C_{\max }-C_{\text {nat }}}
$$

where $L$ (mass/time) is the load of the pollutant under study, $C_{\max }$ (mass/volume) is the maximum acceptable concentration specified by the ambient water quality standard in consideration, and $C_{\text {nat }}$ (mass/volume) is the natural background concentration of that pollutant in the receiving water body.

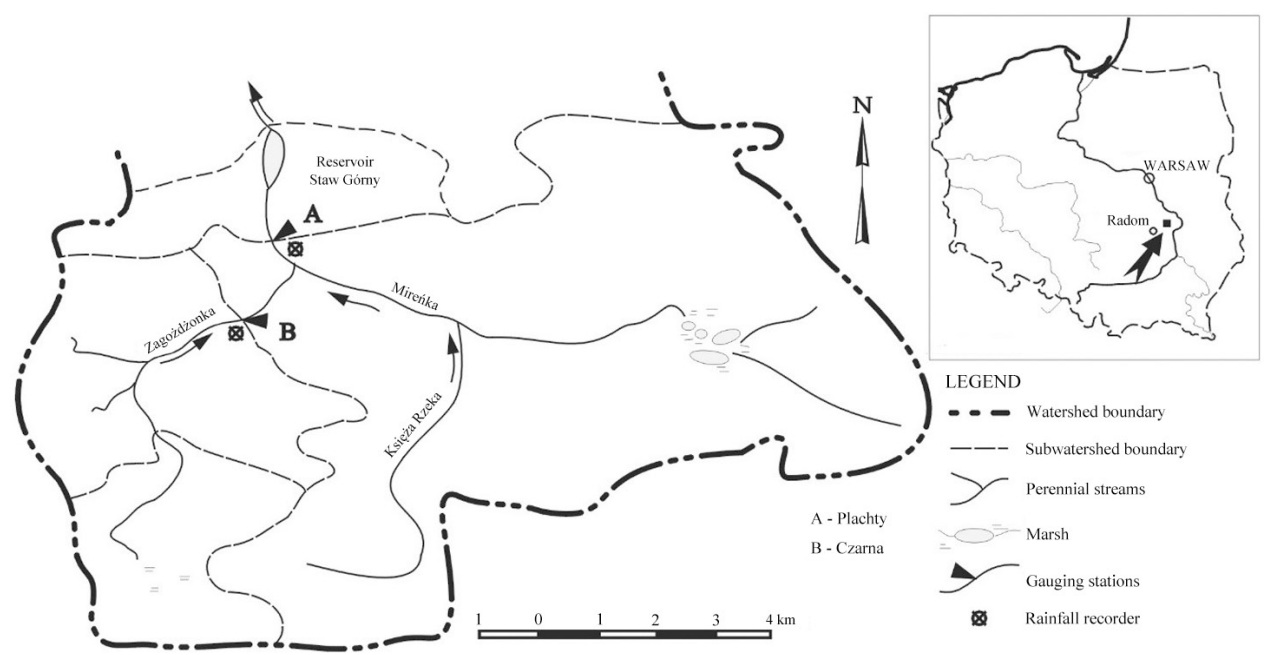

Fig. 1. Locality map of the catchment (upper part of Zagożdżonka River catchment) 


\subsubsection{Determination of $C_{\max }$}

Since 2016 river water quality standards in Poland depend on watercourse type and status of water body. According to the current water quality standards (Dz.U. 2016, poz. 1187) the Zagożdżonka River catchment is a natural water body and belongs to "lowland sandy stream" type of watercourse. This has consequences for the determination of maximum acceptable concentration values $\left(C_{\max }\right)$. For two considered biogenetic water quality indicators, total phosphorus and total nitrogen, the following limits, dependent on water class, are available.

Table 1. Extract form water quality standards (based on Dz.U. 2016, poz. 1187)

\begin{tabular}{|l|c|c|c|}
\hline Indicator & Units & Class I & Class II \\
\hline Total nitrogen & {$[\mathrm{mg} \mathrm{N} / 1]$} & $\leq 3.2$ & $\leq 4.9$ \\
\hline Total phosphorus & {$[\mathrm{mg} \mathrm{P} / 1]$} & $\leq 0.20$ & $\leq 0.30$ \\
\hline
\end{tabular}

Class I means a very good water condition and class II means a good condition. When measured water concentrations are higher than the 2 nd class limits the water quality is described as "not fulfilled of second class standards and water status below good"(Dz.U. 2016, poz. 1187). In this case, the $C_{\max }$ value for determination of $G W F$ was therefore assumed to be $4.9 \mathrm{mgN} / 1$ for total nitrogen and $0.3 \mathrm{mgP} / 1$ for total phosphorus.

The present water quality standards (Dz.U. 2016, poz. 1187) described above, differ from previous ones that were in force 2004-2008, 2008-2011, 2011-2014 and 2014-2016. The most important difference is in the class limits. Due to not distinguishing by watercourse type, old standards (Dz.U. 2014, poz. 1482) were the same for all rivers in Poland. Whether old or present water quality standards are applied has a strong impact on the determination of river quality.

For comparison purposes, the same calculations, using old water quality standards, (Tab. 2) have been included in this analysis.

Table 2. Extract from water quality standards (based on Dz.U. 2014, poz. 1482)

\begin{tabular}{|l|c|c|c|}
\hline Indicator & Units & Class I & Class II \\
\hline Total nitrogen & {$[\mathrm{mg} \mathrm{N} / 1]$} & $\leq 5$ & $\leq 10$ \\
\hline Total phosphorus & {$[\mathrm{mg} \mathrm{P} / \mathrm{l}]$} & $\leq 0.20$ & $\leq 0.4$ \\
\hline
\end{tabular}

For those calculations, the $\mathrm{C}_{\max }$ value for determination of $G W F$ was assumed as $10 \mathrm{mg} \mathrm{N} / 1$ for total nitrogen and $0.4 \mathrm{mg} \mathrm{P} / 1$ for total phosphorus.

\subsubsection{Determination of $C_{n a t}$}

The natural background concentration of the water body is defined as the concentration of a particular substance in the water body that would occur if there were no human disturbances in the catchment (Franke et al. 2013). For human made substances, it could be assumed to be zero, however in case of phosphorus and nitrogen, even without human activities there would be some concentration of these elements due to natural decay processes. As there is often limited historical information or no information at all, estimating natural concentrations can be challenging. One solution is to apply the class one concentration from water quality standards. The disadvantage of such an approach is that, often, in a particular river, the lowest recorded concentration is lower than first class limits. This is the case for the Zagożdżonka River. Therefore the lowest ever measured concentration has been assumed to be the $C_{n a t}$ value for the present investigation.

Historical water quality data for the Zagożdżonka catchment (Hejduk, Banasik 2008; Hejduk et al. 2010; Sawa et al. 2011; Hejduk et al. 2014) establish the lowest ever measured concentration of total nitrogen as $0.58 \mathrm{mg} \mathrm{N} / 1$ and total phosphorus as $0.09 \mathrm{mg} \mathrm{P} / 1$. These values were used as $C_{n a t}$ for further calculations.

\subsubsection{Determination of $L$}

The $L$ parameter (load of pollutants) from the catchment area into the river can be calculated by various methods, depending on available data. The Zagożdżonka catchment is predominantly a rural area so only diffuse sources of water pollution were taken into consideration. In the case of diffuse pollution, the $L$ parameter can be calculated as a multiplication of chemical substances on or into the soil (in mass/time) and $\alpha$ factor, which describes the fraction of applied chemical substances reaching freshwater bodies. Another approach that can be applied is to use surplus (calculated as a difference between the application rate of the chemical substance and the off take rate) multiplied by a leaching-runoff fraction $(\beta)$.

Due to data availability, the first method was used, calculating the $\alpha$ factor separately for phosphorus and nitrogen. The $\alpha$ factor can be calculated by two different approaches. The first approach to determining $\alpha$ uses average leaching-runoff fractions (Franke et al. 2013) where the average value for nitrogen is 0.1 and for phosphorus is 0.03 . Based on statistical data (Hejduk 2011) the average usage of fertilizers in this area is $9.34 \mathrm{~kg} \mathrm{P} /$ ha for phosphorus and $46.72 \mathrm{~kg} \mathrm{~N} /$ ha for nitrogen. Finally by multiplying 
the alpha parameters, fertilizer load and area it is possible to calculate the $L$ value. This approach to $L$ calculation is suggested when there is no local data.

When local data exists, it is possible to estimate the $\alpha$ parameter using the second, more precise method. The necessary data for this approach (Franke et al. 2013) are different for nitrogen and phosphorus. For nitrogen, environmental factors are needed, including $\mathrm{N}$-deposition, soil texture (for leaching and for runoff), natural drainage (for leaching and for runoff), yearly sum of precipitation and agricultural practice (i.e., N-fixation, application rate, plant uptake, and management practice). For phosphorus environmental factors like soil texture, soil erosion and soil $\mathrm{P}$ contents with rain intensity and agricultural practices (application rate, plant uptake, management practice) influence the $\alpha$ parameter.

Data available for the Zagożdżonka catchment (Hejduk 2011) together with parameters from maps, recalculated according to particular factor weight (Franke et al. 2013) and based on following equation:

$$
\alpha=\alpha_{\min }+\left[\frac{\sum_{i} s_{i} \cdot w_{i}}{\sum_{i} w_{i}}\right] \cdot\left(\alpha_{\max }-\alpha_{\min }\right)
$$

where: $\alpha_{\max }, \alpha_{\min }-$ maximum and minimum leaching runoff fraction; $s_{i}$ - leaching runoff potential (values according to Franke et al. 2013); $w_{i}$ - weight of the factor (values according to Franke et al. 2013); give the $\alpha$ factor value for nitrogen equal: 0.11 and for phosphorus: 0.014 .

\subsubsection{Determination of water pollution level}

Water pollution level (WPL), which is a measure of degree of pollution, is defined as the fraction of the waste assimilation capacity consumed and calculated by taking the ratio of the total of grey water footprint in a catchment to the outflow from that catchment. A water pollution level of $100 \%$ means that the waste assimilation capacity has been fully consumed.

\section{Results and discussion}

The comparison of grey water footprint calculated by use of a simplified method (GWF_1 and $\left.G W F_{-} 10\right)$ and more precise method (GWF_2 and GWF_2o) of $\alpha$ factor estimation show differences for both considered pollutants. In the case of phosphorus, the simple method gives significantly higher values of $G W F$ than the more accurate method but for nitrogen did not vary between the different model methodologies (Tab. 3). The more visible difference exists when comparing the values calculated based
Table 3. Comparison of $G W F$ calculated by various methods and for various $C_{\max }$ value

\begin{tabular}{|l|c|c|c|c|}
\hline \multirow{2}{*}{ Unit } & $G W F_{-} 1$ & $G W F_{-} 2$ & $\begin{array}{c}G W F_{-} 1 \mathrm{o} \\
\text { (old standard) }\end{array}$ & $\begin{array}{c}G W F_{2} 2 \mathrm{o} \\
\text { (old standard) }\end{array}$ \\
\cline { 2 - 5 } & \multicolumn{4}{|c|}{$[\mathrm{mm}]$} \\
\hline Phosphorus & 65.14 & 30.40 & 44.13 & 20.59 \\
\hline Nitrogen & 52.80 & 58.08 & 24.21 & 26.63 \\
\hline
\end{tabular}

Table 4. Comparison of WPL calculated by various methods and for various $C_{\max }$ value

\begin{tabular}{|l|c|c|c|c|}
\hline \multirow{2}{*}{ Unit } & $W P L_{-} 1$ & $W P L_{-} 2$ & $\begin{array}{c}W P L \_10 \\
\text { (old standard) }\end{array}$ & $\begin{array}{c}\text { WPL_2o } \\
\text { (old standard) }\end{array}$ \\
\cline { 2 - 5 } & \multicolumn{4}{|c|}{$[\%]$} \\
\hline Phosphorus & 65.4 & 30.5 & 44.1 & 20.6 \\
\hline Nitrogen & 52.8 & 58.1 & 24.2 & 26.6 \\
\hline
\end{tabular}

Table 5. Comparison of threshold year for various method of WPL estimation and for various $C_{\max }$ value

\begin{tabular}{|l|c|c|c|c|}
\hline \multirow{2}{*}{ Unit } & $W P L \_1$ & $W P L \_2$ & $\begin{array}{c}W P L \_10 \\
\text { (old standard) }\end{array}$ & $\begin{array}{c}\text { WPL_2o } \\
\text { (old standard) }\end{array}$ \\
\cline { 2 - 5 } & \multicolumn{4}{|c|}{ Year } \\
\hline Phosphorus & 2033 & 2062 & 2050 & 2070 \\
\hline Nitrogen & 2043 & 2039 & 2066 & 2065 \\
\hline
\end{tabular}

on actual and old water quality standards. For nitrogen, the values of $G W F$ are doubled for actual water quality standards, which is a direct consequence of concentration limits reduction by $50 \%$. Thus, the received values of GWF have a strong impact on the calculation of water pollution level (Tab. 4).

Water pollution level describes the potential capacity of pollutant assimilation. When its value is close to $100 \%$, the violation of a water quality standard is possible; over $100 \%$, the standard is violated. In the case of the Zagożdżonka catchment, based on a long-time outflow average for Czarna gauge $\left(2.3310^{6} \mathrm{~m}^{3}\right)$, the standard violation is not endangered. However, the change in water quality standard can have a strong impact on WPL. The change of nitrogen concentration limits for actual and old quality standards (Tab. 1 and Tab. 2) has caused an almost 50\% increase in WPL in the Zagożdżonka catchment.

The calculations presented in Table 3 and 4 do not consider the water outflow variability during a long period of time. For the Zagożdżonka River, such variability and the long-term water trend of decreased outflow has been investigated (Byczkowski et al. 2001; Banasik, Hejduk 2012; Banasik et al. 2013). When the calculated GWF is referenced not to a long-term average, but yearly outflow, it is possible to analyze the particular years (Fig. 2 and 3) and calculate the WPL. With the exception of 1992 and 2009, the WPL did not exceed $100 \%$ during the considered time period of 1991-2012. Both 1992 and 2012 were the 


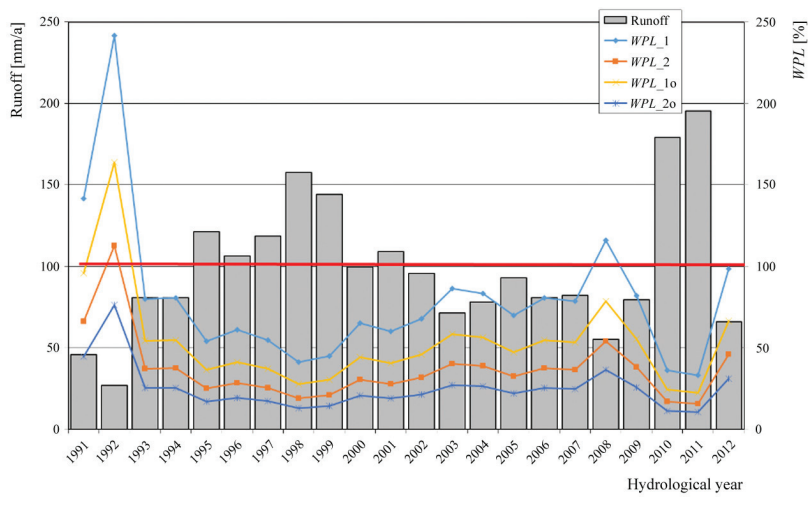

Fig. 2. Phosphorus WPL comparison for hydrological years 1991-2012

driest in the investigated period. It also had an impact on low runoff from the catchment area.

Based on a yearly outflow trend equation (Banasik et al. 2013) it is possible to estimate the threshold year when the WPL for nitrogen and phosphorus will exceed $100 \%$. Due to a lack of knowledge about the variability of fertilizer application, results (Tab. 5) are based on the assumption of the same level fertilizer application for the whole considered time period.

Which methodology of calculation is applied significantly impacts whether the $100 \% W P L$ is reached. In the case of phosphorus, the simple approach of $G W F$ calculation results in a shortened time for possible water standard quality violation and an extension of this time in the case of nitrogen. More restrictive values of water quality norms reduce the time in which water quality sandards apply. This is an indicator of how much time is available to implement mitigation options in order to reduce diffuse pollution in a particular catchment.

\section{Conclusions}

The idea of grey water footprint as applied to a small catchment seems to be a simple and fast procedure for estimating water body assimilation capacity. However, even this approach needs significant input of precise data. Based on long-time monitoring of a small agricultural catchment it was possible to conduct a calculation of $G W F$ as well as WPL. The results can be summarized as follows:

- The calculated grey water footprint for the Zagożdżonka catchment (to the Czarna gauge station) is in the range of $20.59 \mathrm{~mm}$ to $65.4 \mathrm{~mm}$ for phosphorus and $24.2 \mathrm{~mm}$ to $58.1 \mathrm{~mm}$ for nitrogen. These values depend on the exact methodology applied to calculate the GWF and on the assumed natural background concentration.

- The calculated water pollution level for the Zagożdżonka catchment varies from $20.6 \%$ to $65.4 \%$ for phosphorus and from $24.2 \%$ to $58.1 \%$ for nitrogen.

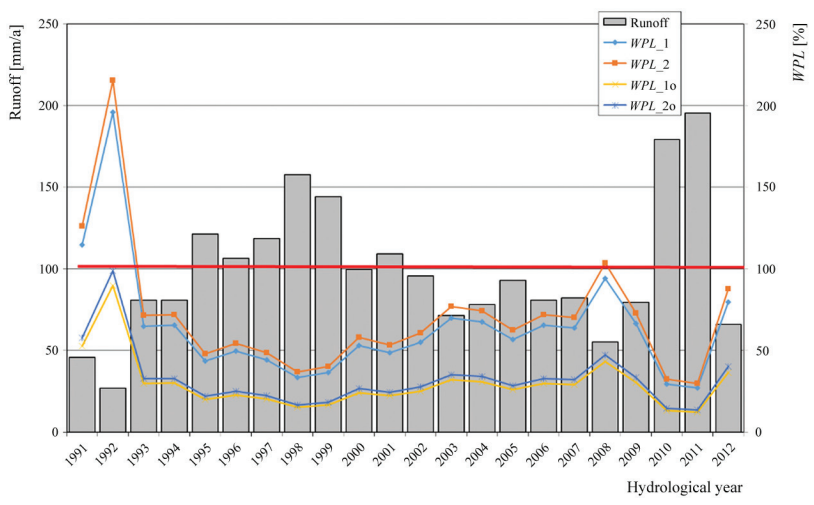

Fig. 3. Nitrogen WPL comparison for hydrological years 1991-2012

The similarity of water pollution level value and grey water footprint values are characteristic only of this particular catchment due to an incidental similarity of catchment area and average outflow.

- Results estimating the year of exceedance of the $100 \%$ WPL threshold varies depending on which methodology of grey water footprint estimation is applied and what maximum acceptable concentration of the considered pollutant is assumed. For the Zagożdżonka River, for phosphorus, in the worst case the $100 \%$ WPL will be exceeded in 2033 and in the best case in 2070. Similarly, for nitrogen the worst case is in year 2039 and in the best case in 2065 .

- The change of water quality standards for phosphorus and nitrogen leads to a decrease in assimilation capacity.

\section{Bibliography}

Banasik K., 1994, Model sedymentogramu wezbrania opadowego w małej zlewni rolniczej, Rozprawy Naukowe i Monografie, 191, SGGW, Warszawa, 120 pp.

Banasik K., Hejduk L., 2012, Long-term changes in runoff from a small agricultural catchment, Soil and Water Resources, 7 (2), 64-72

Banasik K., Hejduk L., Hejduk A., Kaznowska E., Banasik J., Byczkowski A., 2013, Wieloletnia zmienność odpływu z małej zlewni rzecznej w regionie Puszczy Kozienickiej, Sylwan, 157 (8), 578-586

Banasik K., Rudzka E., Śmietanka A., 1996, Eutroficzne wskaźniki zanieczyszczeń w odpływie rzecznym z małej zlewni rolniczej, Przegląd Naukowy Wydziału Melioracji i Inżynierii Środowiska, 11, 23-29

Byczkowski A., Banasik K., Hejduk L., Mandes B., 2001, Wieloletnie tendencje zmian procesów opadu i odpływu w małych zlewniach nizinnych (na przykładzie rzeki Zagożdżonki), [in:] Dynamika obiegu wody w zlewniach rzecznych, J. Jaworski, J. Szkutnicki (eds.), Polskie Towarzystwo Geofizyczne, IMGW, Warszawa, 43-52 
Dz.U. 2014, poz. 1482, Rozporządzenie Ministra Środowiska z dnia 22 października 2014 r. w sprawie sposobu klasyfikacji stanu jednolitych części wód powierzchniowych oraz środowiskowych norm jakości dla substancji priorytetowych, Internetowy System Aktów Prawnych, Sejm RP

Dz.U. 2016, poz. 1187, Rozporządzenie Ministra Środowiska z dnia 21 lipca 2016 r. w sprawie sposobu klasyfikacji stanu jednolitych części wód powierzchniowych oraz środowiskowych norm jakości dla substancji priorytetowych, Internetowy System Aktów Prawnych, Sejm RP

Franke N.A., Boyacioglu H., Hoekstra A.Y., 2013, Grey water footprint accounting: Tier 1 supporting guidelines, Value of Water Research Report Series No. 65, UNESCO-IHE, Delft, Netherlands, available at http://waterfootprint.org/media/ downloads/Report65-GreyWaterFootprint-Guidelines_1.pdf (data access 03.09.2018)

Gerbens-Leenes P.W., Hoekstra A.Y., Bosman R., 2018, The blue and grey water footprint of construction materials: steel, cement and glass, Water Resources and Industry, 19, 1-12, DOI: 10.1016/j.wri.2017.11.002

Hejduk L., 2011, Estimation of influence of land management on river water quality based on model calculations, [in:] Prediction and reduction of diffuse pollution, solid emission and extreme flows from rural areas - case study of small agricultural catchments, K. Banasik, L. Øygarden, L. Hejduk (eds.), Wydawnictwo SGGW, Warszawa, 111-128

Hejduk L., Banasik K., 2008, Zmienność stężenia fosforu w górnej części zlewni rzeki Zagożdżonki, Przegląd Naukowy. Inżynieria i Kształtowanie Środowiska, 17 (4), 57-64

Hejduk L., Banasik K., Hejduk A., 2010, Monitoring ilości i jakości wody w małej zlewni, [in:] Hydrologia w inżynierii i gospodarce wodnej, 68 (1), B. Więzik (ed.), Monografie Komitetu Inżynierii Środowiska Polskiej Akademii Nauk, Warszawa, 401-409

Hejduk L., Kaznowska E., Banasik K., 2014, Ocena zmian jakości wód rzeki Zagożdżonki pod względem wybranych elementów fizyczno-chemicznych, [in:] Monografie KGW-PAN, XX, Volume 1: Hydrologia w inżynierii i gospodarce wodnej, K. Banasik, L. Hejduk, E. Kaznowska (eds.), KGW-PAN, Warszawa, 371-380

Hoekstra A.Y., Chapagain A.K., Aldaya M.M., Mekonnen M.M., 2011, The water footprint assessment manual: setting the global standard, Earthscan, London, Washington, DC, 203 pp.

Kaznowska E., Hejduk L., 2011, Ocena wybranych charakterystyk ilościowych i jakościowych okresów bezwezbraniowych w rzece Zagożdżonce, Przegląd Naukowy. Inżynieria i Kształtowanie Środowiska, 20 (2), 108-118

Li C., Xu M., Wang X., Tan Q., 2017, Spatial analysis of dualscale water stresses based on water footprint accounting in the Haihe River Basin, China, Ecological Indicators, 92, 254-267, DOI: 10.1016/j.ecolind.2017.02.046

Liu C., Kroeze C., Hoekstra A.Y., Gerbens-Leenes W., 2012, Past and future trends in grey water footprints of anthropogenic nitrogen and phosphorus inputs to major world rivers, Ecological Indicators, 18, 42-49, DOI: 10.1016/j. ecolind.2011.10.005

Mali S.S., Singh D.K., Sarangi A., Parihar S.S., 2017, Crop water footprints with special focus on response formulation: the case of Gomti river basin (India), Environmental Earth Sciences, 76, DOI: 10.1007/s12665-017-7121-8

Martínez-Alcalá I., Pellicer-Martínez F., Fernández-López C., 2018, Pharmaceutical grey water footprint: accounting, influence of wastewater treatment plants and implications of the reuse, Water Research, 135, 278-287, DOI: 10.1016/j. watres.2018.02.033

Sawa K., Hejduk L., Deelstra J., Øygarden L., 2011, Nutrient output from rural areas on the example of two catchments Skuterud and Zagożdżonka, Annals of Warsaw University of Life Sciences - SGGW. Land Reclamation, 43 (1), 71-85

Zhi Y., Yang Z., Yin X., Hamilton P.B., Zhang L., 2015, Using gray water footprint to verify economic sectors' consumption of assimilative capacity in a river basin: model and a case study in the Haihe River Basin, China, Journal of Cleaner Production, 92, 267-273, DOI: 10.1016/j. jclepro.2014.12.058 